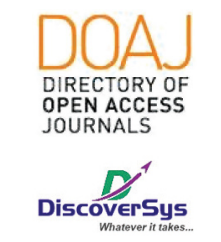

Published by DiscoverSys

\section{Pengaruh ekspresi Vascular Endothelial Growth Factors (VEGF) post-neoadjuvant kemoterapi terhadap respon kemoterapi (huvos), local recurrence, metastasis, dan survival pada pasien osteosarkoma}

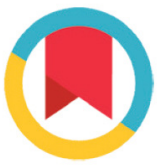

CrossMark

\author{
Kadek Ayu Candra Dewi ${ }^{1 *}$
}

\title{
ABSTRACT
}

Background: Overexpression of VEGF before therapy has been associated with decreased survival and poor prognosis of osteosarcoma patients, but VEGF expression in osteosarcoma patients following receiving neoadjuvant chemotherapy has not been much elucidated. The purpose of this study was to determine the effect of VEGF expression after neoadjuvant chemotherapy on chemotherapy responses (HUVOS), local recurrence, metastases and survival of osteosarcoma patients.

Methods: A cross-sectional study was conducted in Jakarta during the 2009-2010 period to 19 osteosarcoma patients at Cipto Mangunkusumo Hospital, Jakarta. Data on patient's characteristics, VEGF expression after chemotherapy, local recurrence, metastasis, chemotherapy response and survival in osteosarcoma patients were recorded and analysed using statistical analysis. All data were analysed using SPSS software version 16 for Windows.

Results: Most respondents were male (63.2\%), age $>14$ years (84.2\%), stage IIB (94.7\%), poor HUVOS $(73.7 \%)$, size $<10 \mathrm{~cm}$ $(63,2 \%)$, positive VEGF expression (57.9\%), negative metastasis (73.7\%), and death (73.7\%). There was no significant relationship between VEGF expression and all parameters assessed $(P>0.05)$. Conclusion: VEGF expression by living osteosarcoma cells after neoadjuvant chemotherapy is not significantly related to histological response (HUVOS), local recurrence and metastasis, but has a significant relationship with good survival.

Keywords: Osteosarcoma, VEGF, angiogenesis, prognosis, HUVOS

Cite This Article: Dewi, K.A.C. 2019. Pengaruh ekspresi Vascular Endothelial Growth Factors (VEGF) post-neoadjuvant kemoterapi terhadap respon kemoterapi (huvos), local recurrence, metastasis, dan survival pada pasien osteosarkoma. Intisari Sains Medis 10 (3): 608-615. D0I: 10.15562/ism.v10i3.590

\section{ABSTRAK}

${ }^{1}$ Departemen Orthopaedi dan Traumatologi, Fakultas Kedokteran, Universitas Udayana, RSUP Sanglah, Bali, Indonesia

*Korespondensi: Kadek Ayu Candra Dewi; Departemen Orthopaedi dan Traumatologi, Fakultas Kedokteran, Universitas Udayana, RSUP Sanglah, Bali, Indonesia; cdewi144@gmail.com

Diterima: 22-08-2019 Disetujui: 21-09-2019 Diterbitkan: 01-12-2019
Latar Belakang: Ekspresi yang berlebih dari VEGF sebelum terapi telah dihubungkan dengan penurunan survival dan prognosa yang jelek dari pasien osteosarkoma, namun ekspresi VEGF pada pasien osteosakoma setelah mendapat neoadjuvant kemoterapi belum banyak diteliti. Tujuan dari penelitian ini adalah untuk mengetahui pengaruh ekspresi VEGF setelah neoadjuvant kemoterapi terhadap respon kemoterapi (HUVOS), local recurrence, metastase dan survival pasien osteosarkoma.

Metode: Penelitian dengan desain potong lintang dilakukan di Jakarta pada periode 2009-2010 terhadap 19 pasien osteosarkoma di RS Cipto Mangunkusumo, Jakarta. Data karakteristik pasien, ekspresi VEGF setelah kemoterapi, local recurrence, metastase, respon kemoterapi dan survival pada pasien osteosarkoma dicatat dan dianalisis menggunakan uji statistik. Seluruh data dianalisis menggunakan piranti lunak SPSS versi 16 untuk Windows.

Hasil: Sebagian besar responden berjenis kelamin laki-laki $(63,2 \%)$, usia > 14 tahun $(84,2 \%)$, stadium IIB $(94,7 \%)$, HUVOS buruk $(73,7 \%)$, ukuran $<10 \mathrm{~cm}(63,2 \%)$, ekspresi VEGF positif $(57,9 \%)$, metastasis negatif $(73,7 \%)$, dan meninggal $(73,7 \%)$. Tidak terdapat hubungan yang bermakna antara ekspresi VEGF dengan seluruh parameter yang dinilai $(P>0,05)$.

Kesimpulan: Ekspresi VEGF oleh sel osteosarkoma yang masih hidup setelah neoadjuvant kemoterapi tidak berhubungan bermakna dengan respon histologi (HUVOS), local recurrence dan metastase, namun memiliki hubungan yang bermakna dengan survival yang baik. respon kemoterapi (huvos), local recurrence, metastasis, dan survival pada pasien osteosarkoma. Intisari Sains Medis 10 (3): 608-615. D0I: 10.15562/ism.v10i3.590 


\section{PENDAHULUAN}

Osteosarkoma adalah tumor primer ganas tulang yang paling sering dijumpai pada remaja dan dewasa muda. ${ }^{1,2}$ Meskipun dengan perkembangan dalam multi modal terapi yang terdiri dari kemoterapi adjuvant agresif dan wide eksisi dari tumor, hanya mampu meningkatkan survival rate sampai 65 $75 \%$ untuk pasien dengan osteosarkoma tanpa metastasis $^{3,4}$ Metastasis paru terjadi pada \pm 40 - 50 $\%$ pasien dan tetap merupakan penyebab utama dari kematian. Pada kasus seperti tersebut di atas, 5-year survival rate hanya sekitar $28 \%{ }^{5,6}$

Beberapa faktor telah dihubungkan dengan prognosis penderita, antara lain adanya metastasis saat diagnosis, nilai HUVOS (respon terhadap neoadjuvant kemotherapi), adanya, resectability dari tumor, stadium, umur, sex, lokasi, ukuran tumor, local recurrence dan hasil laboratorium (SAP). ${ }^{1,2,7,8}$ Saat ini, selain dari pada adanya metastasis saat diagnosis, respon terhadap neoadjuvant kemotherapi secara histologis (HUVOS) merupakan faktor prognosa yang paling dapat diandalkan dan reproducible dalam menilai survival. ${ }^{9,10}$

Nilai HUVOS yang jelek dihubungkan dengan angka kekambuhan yang tinggi dan survival yang jelek. Beberapa penelitian menyiratkan adanya ekspresi yang berbeda antara pasien yang berespon baik terhadap kemoterapi dan yang tidak. Dengan berkembangnya berbagai pilihan terapi saat ini, berbagai uji klinis dilakukan untuk meningkatkan survival pada pasien - pasien yang memiliki nilai HUVOS yang jelek ini. ${ }^{9-11}$ Namun belum ada yang menunjukkan hasil menjanjikan.

VEGF (vascular endothelial growth factor) merupakan salah satu penanda angiogenesis pada tumor solid. Beberapa penelitian menunjukkan hubungan antara ekspresi VEGF pada pasien osteosarkoma sebelum mendapat terapi dengan survival dan kemungkinan terjadinya metastasis. ${ }^{9-12}$ Namun hubungan antara ekspresi VEGF setelah kemoterapi neoadjuvan dengan angka kekambuhan, survival dan kemungkinan terjadinya metastasis belum banyak diteliti.

Berdasarkan beberapa hal yang telah dipaparkan di atas, maka tujuan dari penelitian ini adalah untuk mengetahui hubungan antara ekspresi VEGF setelah kemoterapi terhadap respon kemotherapi (nilai HUVOS) dan survival/kesintasan pada pasieng dengan osteosarkoma.

\section{METODE PENELITIAN}

Desain penelitian yang digunakan adalah potong lintang (cross-sectional) studi dengan analisa secara deskriptif mengenai karakteristik pasien (umur, jenis kelamin, ukuran, lokasi, jenis osteosarkoma dan kadar SAP post kemoterapi), ekspresi VEGF setelah kemoterapi, local recurrence, metastase, respon kemotherapi dan survival pada pasien pasien osteosarkoma serta analisa analitik untuk mengetahui hubungan antara ekspresi VEGF setelah kemoterapi dengan karakteristik pasien, metastase, local recurrence, respon kemotherapi dan survival pada pasien - pasien osteosarkoma.

Penelitian dilakukan di Jakarta dimulai dari Januari 2009 - Juli 2010. Dalam rentang waktu ini semua pasien dengan osteosarkoma yang terdaftar dalam buku besar tumor bagian Orthopedi dan Traumatologi dan rekam medis serta memenuhi kriteria inklusi dan eksklusi dimasukkan ke dalam penelitian.

Kriteria eklusi meliputi pasien osteosarkoma yang blok parafin post neoadjuvant kemoterapi tidak tersedia atau yang blok parafinnya sudah rusak, pasien osteosarkoma yang tidak dapat ditentukan nilai HUVOS nya, pasien dengan osteosarkoma multiple, pasien osteosarkoma dengan kondisi umum yang sangat buruk saat pertama kali mendapat perawatan sehingga tidak sempat di work-up dengan sempurna, dan pasien - pasien osteosarkoma yang menolak perawatan medis sehingga tidak dapat diikuti perkembangannya.

Semua data karakteristik, metastase, dan HUVOS didapat dari medical record, buku besar tumor maupun catatan dari PA. Ekspresi VEGF setelah kemoterapi didapatkan melalui pengecatan imunohistokimia terhadap blok parafin setelah operasi.

Blok parafin dipotong dengan ketebalan 5 $\mathrm{nm}$, kemudian di-deparafinisasi dalam xylol dan direhidrasi dengan alkohol. Dilakukan bloking terhadap endogen peroxida dengan methanol, kemudian di panaskan dalam microwave. Setelah dicuci dalam PBS, sediaan diberi antibodi terhadap VEGF dengan dilusi 1:200 (Biocare Medical). Pengikatan antibodi kemudian diperjelas dengan DAB

Peparat imunohistokimia dinilai oleh ahli PA yang sama. Diambil 5 daerah hpf (400x) yang paling banyak mengandung sel - sel tumor dan dihitung rata - rata persentase tumor yang mengekspresikan VEGF dari kelima daerah tersebut. Setelah datadata tersebut terkumpul dilakukan evaluasi. VEGF dinyatakan sebagai diekspresikan dengan kuat bila nilai persentase sel yang mengekspresikan VEGF > $50 \%$, positif lemah bila persentase berada antara $>$ $10-50 \%$, dan negatif bila $\leq 10 \%$.

\section{HASIL}

Daribulan januari sampai Januari 1999 sampai bulan Desember 2008 terdapat 19 pasien osteosarkoma 
yang berobat ke RS Cipto Mangunkusumo (RSCM) yang memenuhi kriteria inklusi dan eksklusi. Data deskriptif dari kedua puluh pasien tersebut seperti disajikan Tabel 1.

Umur pasien dalam penelitian ini berkisar antara 9 sampai 47 tahun, rerata umur pasien adalah 23 tahun dengan nilai tengah 20 tahun. Sebagian besar pasien berusia 16 tahun. Kadar Serum Alkaline Phosphatase ( SAP) berkisar antara normal sampai 5 kali normal, dengan nilai tengah 1,3 kali normal. Selain distal femur dan proximal tibia, lokasi osteosarkoma pada penelitian ini meliputi proximal femur, proximal fibula, proximal

Tabel 1. Karakteristik responden penelitian

\begin{tabular}{|c|c|c|c|}
\hline \multicolumn{2}{|c|}{ Parameter } & \multirow{2}{*}{$\frac{\text { Jumlah }(\mathbf{N}=\mathbf{1 9})}{7}$} & \multirow{2}{*}{$\frac{\text { Persentase (\%) }}{36,8}$} \\
\hline Jenis kelamin & Perempuan & & \\
\hline & Laki-laki & 12 & 63,2 \\
\hline \multirow[t]{2}{*}{ Umur } & $<=14$ tahun & 3 & 15,8 \\
\hline & $>14$ tahun & 16 & 84,2 \\
\hline \multirow[t]{2}{*}{ Ukuran } & $>10 \mathrm{~cm}$ & 7 & 36,8 \\
\hline & $<=10 \mathrm{~cm}$ & 12 & 63,2 \\
\hline \multirow[t]{2}{*}{ SAP } & Tinggi & 10 & 52,6 \\
\hline & Normal & 9 & 47,4 \\
\hline \multirow[t]{3}{*}{ Lokasi } & Proximal tibia & 7 & 36,8 \\
\hline & Distal femur & 5 & 26,3 \\
\hline & Lain-lain & 7 & 36,8 \\
\hline \multirow[t]{2}{*}{ Metastasis } & Positif & 5 & 26,3 \\
\hline & Negatif & 14 & 73,7 \\
\hline \multirow[t]{2}{*}{ Stadium } & IIB & 18 & 94,7 \\
\hline & III & 1 & 5,3 \\
\hline \multirow[t]{4}{*}{ Huvos } & 1 & 8 & 42,1 \\
\hline & 2 & 6 & 31,6 \\
\hline & 3 & 4 & 21,1 \\
\hline & 4 & 1 & 5,3 \\
\hline \multirow[t]{2}{*}{ Huvos } & Buruk (1-2) & 14 & 73,7 \\
\hline & Baik (3-4) & 5 & 26,3 \\
\hline \multirow[t]{2}{*}{ Ekspresi VEGF } & Positif & 11 & 57,9 \\
\hline & Negatif & 8 & 42,1 \\
\hline \multirow[t]{3}{*}{ Ekspresi VEGF } & Positif kuat & 7 & 36,8 \\
\hline & Positif lemah & 4 & 21,1 \\
\hline & Negatif & 8 & 42,1 \\
\hline \multirow[t]{2}{*}{ Local recurent } & Positif & 8 & 42,1 \\
\hline & Negatif & 11 & 57,9 \\
\hline \multirow[t]{6}{*}{ PA post } & Konvensional & 12 & 63,2 \\
\hline & Periosteal & 4 & 21,1 \\
\hline & Giant cell & 1 & 5,3 \\
\hline & High grade & 1 & 5,3 \\
\hline & Small cell & 1 & 5,3 \\
\hline & Sensor & 14 & 73,7 \\
\hline \multirow[t]{3}{*}{ Meninggal } & Ya & 5 & 26,3 \\
\hline & Tidak & 3 & 15,8 \\
\hline & $\begin{array}{l}\text { Hilang dari } \\
\text { pengamatan }\end{array}$ & 11 & 57,9 \\
\hline
\end{tabular}

humerus, distal humerus dan distal radius. Dari 5 pasien dengan metastase positif, satu pasien datang dengan metastase paru, pasien lain mendapat metastase selama follow up (Tabel 1).

Semua pasien mendapat kemoterapi neoadjuvant berdasarkan protap RSCM berupa Cysplatin $100 \mathrm{mg} / \mathrm{m}^{2}$ dan doxorubisin $25 \mathrm{mg} / \mathrm{m}^{2}$ bagi pasien usia $>14$ th dan cysplatin, ifosfamid dan adriamisin bagi pasien $\leq 14$ tahun. Setiap pasien diharapkan dapat diterapi dengan tiga siklus neoadjuvant kemoterapi, namun pada penelitian ini dua pasien hanya mendapat 1 siklus neoadjuvant kemoterapi dan dua pasien hanya mendapat 2 siklus kemoterapi karena alasan sosial ekonomi. Lima pasien menjalani limb ablasi, dua pasien dengan tumor di proximal fibula diterapi dengan wide reseksi dan 12 pasien menjalani limb salvage (satu dengan prostesis, 9 ECI dan 2 Autoclave ). Setelah operasi limb salvage atau ablasi pasien dibagi menjadi dua, yang berespon baik terhadap kemoterapi neoadjuvant (HUVOS 3 dan 4 ) dan yang tidak (HUVOS 1 dan 2). Pasien yang berespon baik mendapatkan kemoterapi adjuvant sesuai dengan kemoterapi neoadjuvantnya, sedangkan untuk pasien yang berespon buruk, kemoterapi diganti dengan regimen sesuai dengan regimen Memorial Sloan Kattering (TIO) yang meliputi Cisplatin, doxorubisin, Methotrexate, Bleomisin, Cyclofosfamid dan Dactionimysin. Lima pasien tidak mendapatkan kemoterapi adjuvant. Sedangkan terdapat tiga pasien dengan VEGF negatif dan dua pasien dengan VEGF positif kuat (Tabel 1). Pemeriksaan imunohistokimia ekspresi VEGF pada osteosarkoma dapat dilihat pada Gambar 1.

Rerata follow up dilakukan selama 24 bulan dengan nilai tengah 19 bulan. Rentang follow up adalah 4 sampai 48 bulan. Sampai akhir masa penelitian terdapat $5(26,3 \%)$ pasien meninggal dunia, tiga pasien (15,8\%) masih hidup dan 11 (57,9 $\%)$ pasien hilang dari pengamatan. Kekambuhan (local recurrence) terjadi pada delapan $(42,1 \%)$ pasien pada rerata 28 bulan setelah operasi reseksi. Rentang waktu terjadinya kekambuhan adalah 10 - 43 bulan. Dari hasil imunohistokimia dengan antibodi terhadap VEGF dari 19 sediaan parafin blok pasien osteosarkoma post operasi, didapatkan tujuh $(36,8 \%)$ sediaan dengan stainning positif kuat, empat $(21,1 \%)$ sediaan dengan stainning positif lemah dan delapan (42,1\%) sediaan dengan stainning negatif (Tabel 1).

Hasil tabel silang dari dua kelas VEGF positif dan negatif terhadap karakteristik pasien seperti tercantum pada Tabel 2. Hasil menunjukkan bahwa tidak terdapat hubungan antara ekspresi VEFG dengan karakteristik pasien $(P>0,05)$. Sedangkan 
Tabel 2. Hubungan VEGF positif (+) dan negatif (-) terhadap karakteristik dan keluaran pasien

\begin{tabular}{|c|c|c|c|c|c|c|c|c|}
\hline \multicolumn{2}{|c|}{ Parameter } & \multirow{2}{*}{$\begin{array}{c}\begin{array}{c}\text { VEGF (+) } \\
(\mathbf{N}=11)\end{array} \\
1\end{array}$} & \multirow{2}{*}{$\begin{array}{c}\% \\
9,1\end{array}$} & \multirow{2}{*}{$\begin{array}{c}\begin{array}{c}\text { VEGF (-) } \\
(\mathbf{N}=\mathbf{8})\end{array} \\
2\end{array}$} & \multirow{2}{*}{$\begin{array}{l}\% \\
25\end{array}$} & \multirow{2}{*}{$\begin{array}{c}\mathbf{P} \\
0,54\end{array}$} & \multirow{2}{*}{$\begin{array}{c}\text { OR } \\
0,3\end{array}$} & \multirow{2}{*}{$\begin{array}{c}\mathbf{9 5} \% \mathbf{I K} \\
0,022-4,060\end{array}$} \\
\hline Umur & $\leq 14$ th & & & & & & & \\
\hline & $>14$ th & 10 & 90,9 & 6 & 75 & & & \\
\hline \multirow[t]{2}{*}{ Ukuran } & $\leq 10$ & 7 & 63,6 & 5 & 62,5 & 1 & 0,95 & $0,14-6,28$ \\
\hline & $>10$ & 4 & 36,4 & 3 & 37,5 & & & \\
\hline \multirow[t]{4}{*}{ Lokasi } & proksimal tibia & 5 & 45,5 & 2 & 25 & 0,55 & - & - \\
\hline & Distal Femur & 3 & 27,3 & 2 & 25 & & & \\
\hline & Lain - lain & 3 & 27,3 & 4 & 50 & & & \\
\hline & Perempuan & 4 & 36,4 & 3 & 37,5 & & & \\
\hline \multirow[t]{2}{*}{ Sex } & Laki - laki & 7 & 63,6 & 5 & 62,5 & 1 & 0,95 & $0,14-6,28$ \\
\hline & IIB & 11 & 100 & 7 & 87,5 & & & \\
\hline \multirow[t]{2}{*}{ Stadium } & III & 0 & 0 & 1 & 12,5 & 0,42 & 1,143 & $0,88-1,4$ \\
\hline & Konvensional & 8 & 72,7 & 4 & 50 & & & \\
\hline \multirow[t]{4}{*}{ Jenis tumor } & Periosteal & 3 & 27,3 & 1 & 12,5 & 0,28 & - & - \\
\hline & Giant cell ost & 0 & 0 & 1 & 12,5 & & & \\
\hline & High grade & 0 & 0 & 1 & 12,5 & & & \\
\hline & Small cell & 0 & 0 & 1 & 12,5 & & & \\
\hline \multirow[t]{2}{*}{ Kadar SAP } & Tinggi & 7 & 63,6 & 3 & 33,3 & 0,37 & 3,5 & $0,549-22,304$ \\
\hline & Normal & 4 & 36,4 & 6 & 66,7 & & & \\
\hline \multirow[t]{2}{*}{ Local recurrent } & Positif & 7 & 63.6 & 1 & 12.5 & 0,059 & 12,25 & $1,080-138,9$ \\
\hline & Negatif & 4 & 36.4 & 7 & 87.5 & & & \\
\hline \multirow[t]{2}{*}{ HUVOS } & Buruk ( 1,2 ) & 8 & 72.7 & 6 & 75 & 1 & 0,889 & $0,111-7,107$ \\
\hline & Baik ( 3,4$)$ & 3 & 27.3 & 2 & 25 & & & \\
\hline \multirow[t]{4}{*}{ HUVOS } & 1 & 5 & 44.5 & 3 & 37.3 & 0,556 & - & - \\
\hline & 2 & 3 & 27.3 & 3 & 37.3 & & & \\
\hline & 3 & 3 & 27.3 & 1 & 12.5 & & & \\
\hline & 4 & 0 & 0 & 1 & 12.5 & & & \\
\hline \multirow[t]{2}{*}{ Metastasis } & Positif & 3 & 27,3 & 2 & 25 & 1 & 1,125 & $0,141-8,995$ \\
\hline & Negatif & 8 & 72.7 & 6 & 75 & & & \\
\hline
\end{tabular}

Tabel 3. Hubungan antara VEGF positif kuat $(++)$, positif lemah (+) dan negatif $(-)$ terhadap keluaran pasien

\begin{tabular}{|c|c|c|c|c|c|c|c|c|}
\hline \multicolumn{2}{|c|}{ Parameter } & \multirow{2}{*}{$\begin{array}{c}\begin{array}{c}\text { VEGF (++) } \\
(\mathbf{N}=7)\end{array} \\
4\end{array}$} & \multirow{2}{*}{$\frac{\%}{57,1}$} & \multirow{2}{*}{$\begin{array}{c}\begin{array}{c}\text { VEGF (+) } \\
(\mathrm{N}=4)\end{array} \\
3\end{array}$} & \multirow{2}{*}{$\begin{array}{l}\% \\
75\end{array}$} & \multirow{2}{*}{$\begin{array}{c}\text { VEGF (-) } \\
(\mathbf{N}=\mathbf{8}) \\
1\end{array}$} & \multirow{2}{*}{$\begin{array}{l}\% \\
12,5\end{array}$} & \multirow{2}{*}{$\begin{array}{c}\mathbf{P} \\
0,071\end{array}$} \\
\hline Local recurrent & Positif & & & & & & & \\
\hline & Negatif & 3 & 42,9 & 1 & 25 & 7 & 87,5 & \\
\hline \multirow[t]{2}{*}{ HUVOS } & Buruk $(1,2)$ & 5 & 71,4 & 3 & 75 & 6 & 75 & 0,986 \\
\hline & Baik $(3,4)$ & 2 & 28,6 & 1 & 25 & 2 & 25 & \\
\hline \multirow[t]{4}{*}{ HUVOS } & 1 & 3 & 42,9 & 2 & 50 & 3 & 37,5 & \\
\hline & 2 & 2 & 28,6 & 1 & 25 & 3 & 37,5 & \\
\hline & 3 & 2 & 28,6 & 1 & 25 & 1 & 12,5 & 0,907 \\
\hline & 4 & 0 & 0 & 0 & 0 & 1 & 12,5 & \\
\hline \multirow[t]{2}{*}{ Metastasis } & Positif & 2 & 28,6 & 1 & 25 & 1 & 25 & 0,986 \\
\hline & Negatif & 5 & 71,4 & 3 & 75 & 6 & 75 & \\
\hline
\end{tabular}




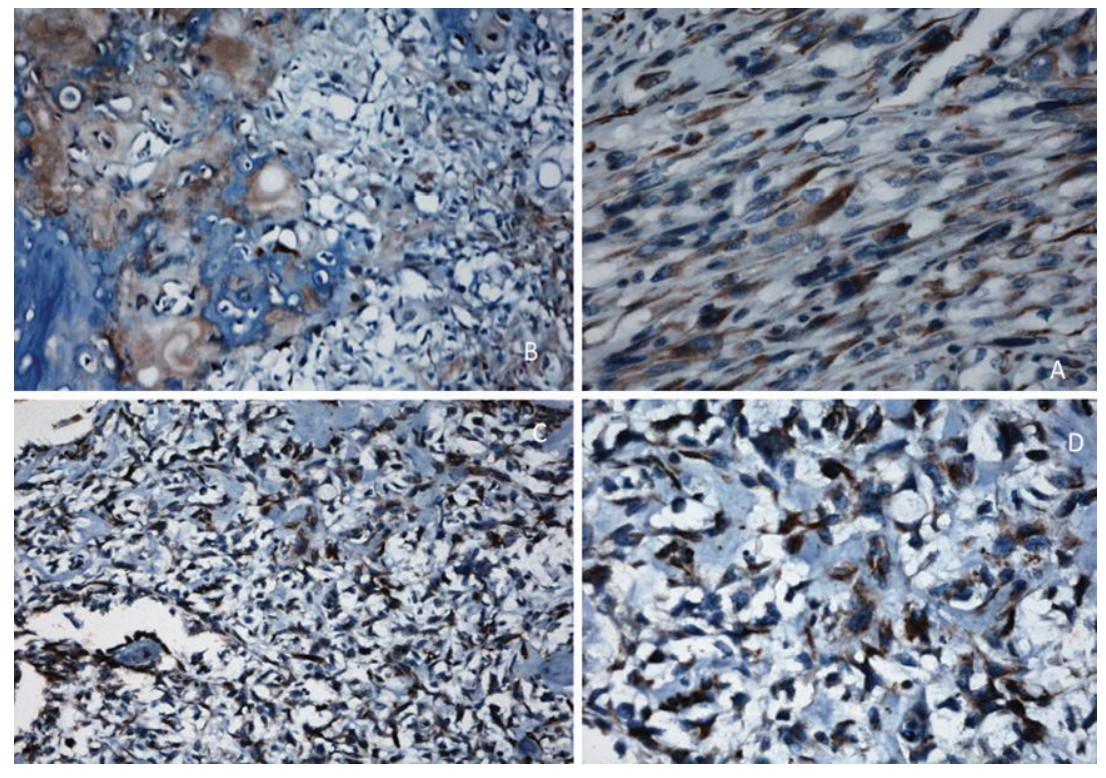

Gambar 1. (A) Osteosarkoma subtipe fibroblastik (400x); (B) Osteosarkoma subtipe condroblastik (200x); (C) Osteoid dengan VEGF positif (200x); (D) Osteoid dengan VEGF positif (400x)

hasil tabulasi silang antara klas VEGF positif dan negatif terhadap keluaran pasien (kekambuhan, nilai HUVOS, dan metastasis) juga kembali dicantumkan pada Tabel 2 dimana menunjukan hasil yang tidak bermakna $(\mathrm{P}>0,05)$

Hasil tabulasi untuk mengetahui hubungan antara ekspresi VEGF yang bersifat positif kuat, lemah, maupun negatif terhadap keluaran pasien ditunjukkan pada Tabel 2. Hasil penelitian ini menunjukkan bahwa tidak terdapat hubungan yang bermakna antara kekuatan ekspresi VEGF terhadap keluaran pasien $(\mathrm{P}>0,05)$ (Tabel 3).

Hubungan antara kekuatan ekspresi VEGF terhadap keluaran pasien ditunjukkan pada Tabel 3. Hasil penelitian ini menunjukkan hal serupa dimana tidak terdapat hubungan yang bermakna antara status ekspresi VEGF (positif kuat, positif lemah, dan negatif) terhadap keluaran pasien $(\mathrm{P}>0,05)$ (Tabel 3).

Dari analisa log rank didapatkan bahwa survival pasien dengan ekspresi VEGF positif lebih baik dibandingkan dengan pasien dengan VEGF negatif secara bermakna $(P=0.04)$. Pasien dengan VEGF positif lemah memiliki survival terbaik, diikuti oleh pasien dengan VEGF positif kuat dan VEGF negatif. Nilai tengah untuk survival pasien dengan VEGF positif adalah 48 bulan (positif lemah 48 bulan dan positif kuat 42 bulan) dan untuk pasien dengan VEGF negatif adalah 30 bulan. Dari sembilan pasien dengan VEGF positif yang tersensor, tiga orang pasien masih hidup sampai akhir penelitian, dan enam orang hilang dari pengamatan. Sedangkan dari lima pasien dengan VEGF negative yang tersensor semuanya hilang dari pengamatan.

Dari analisa multivariate (Log regression) didapatkan bahwa VEGF negatif dan umur di bawah 14 tahun berpengaruh paling besar terhadap survival yang jelek.

\section{PEMBAHASAN}

Osteosarcoma adalah tumor primer ganas tulang yang paling sering dijumpai pada remaja dan dewasa muda. Meskipun dengan perkembangan dalam multi modal terapi yang terdiri dari kemoterapi adjuvant agresif dan wide eksisi dari tumor, survival rate hanya meningkat sampai $65-75 \% \cdot{ }^{13-15}$

Sel tumor berespon seperti layaknya sel normal dalam keadaan hipoxia yaitu dengan mengaktifkan jalan signal yang menginduksi proliferasi, angiogenesis dan apoptosis. Hipoksia dalam tumor telah lama diketahui berhubungan dengan resistensi terhadap kemoterapi dan radioterapi demikian pula dengan sifat tumor yang lebih ganas. ${ }^{16-20}$

Angiogenesis adalah suatu proses vital dalam pertumbuhan sel kanker. peningkatan angiogenesis adalah langkah kunci dalam mempertahankan pertumbuhan tumor dan mungkin juga merupakan faktor penting untuk metastase. Dalam banyak faktor yang berperan dalam angiogenesis, VEGF telah dikenal sebagai faktor yang paling dominan dan penting. ${ }^{21-24}$

Beberapa studi telah mempelajari signifikansi klinis dari penanda biologis yang berhubungan dengan angiogenesis (VEGF, CD31, CD34 dll) pada osteosarkoma, tapi hasil yang mereka dapatkan bertentangan dan hanya sedikit studi yang melibatkan jumlah pasien yang besar. ${ }^{25-27}$

Lee dkk dengan menggunakan biopsi dari 30 pasien osteosarkoma, mendeteksi transkripsi mRNA VEGF pada semua pasien dengan osteosarkoma primer. Sembilan sediaan xenograft dianalisa dan mereka menemukan bahwa jumlah pembuluh darah pada tumor yang positif mengekspresikan VEGF lebih banyak dari pada yang tidak. Lee dkk memperlihatkan bahwa pasien dengan tumor mengekspresikan VEGF mempunyai prognosa lebih buruk. ${ }^{28}$

Hubungan antara survival dan ekspresi VEGF diteliti oleh Kaya. Kaya dkk mempelajari 27 sample osteosarkoma primer dan menemukan VEGF positif pada $63 \%$ dari sample. Kepadatan mikrovaskuler lebih tinggi pada tumor yang positif mengekspresikan VEGF dari pada yang tidak. Kaya juga melaporkan bahwa ekspresi VEGF pada lokasi primer osteosarkoma yang belum mendapat neoadjuvant, mempunyai nilai prediksi untuk metastase paru dan prognosis yang buruk. ${ }^{29}$

Ekspresi VEGF pada sel osteosarkoma yang masih hidup setelah kemoterapi diteliti oleh Charity 
dkk. Mereka mencari hubungan antara ekspresi VEGF pada sel tumor yang masih hidup setelah neoadjuvant kemoterapi dengan survival dan menyimpulkan bahwa ekspresi VEGF padalebih dari $25 \%$ sel tumor yang masih hidup setelah kemoterapi neoadjuvant merupakan faktor independent yang menentukan buruknya survival. Penelitian ini dilakukan pada 48 pasien osteosarkoma stadium IIB yang berlokasi sekitar lutut. Neoadjuvant yang diberikan adalah multidrugs yang meliputi doxorubysin dan cysplatin ${ }^{30}$

Quan meneliti ekspresi penanda angiogenesis (VEGF dan EMMPRIN) pada 65 pasien osteosarkoma dan menghubungkannya dengan survival dan parameter patologi dan klinis. Dalam penelitian ini ditemukan hubungan yang bermakna antara ekspresi EMMPRIN dan VEGF dengan banyaknya sel yang nekrosis, stadium yang tingi, angka bebas tumor dan survival yang rendah. ${ }^{31} \mathrm{Oda}$ membandingkan ekspresi VEGF dan CXCR4 antara lokasi primer dan metastasis paru pada 30 pasien osteosarkoma yang mengalami metastasis paru dan menemukan bahwa tidak ada perbedaan ekspresi VEGF antara lokasi primer dan metastasis, namun ekspresi VEGF pada lokasi primer berhubungan bermakna dengan tumbuhnya metastasis paru. ${ }^{32}$

Hasil yang berlawanan didapatkan oleh Kreuter. Dalam studinya yang melibatkan jumlah pasien yang cukup besar, Kreuter mendapatkan bahwa kadar yang tinggi dari kepadatan mikro vaskuler yang positif terhadap CD31 ( penanda aktifnya angiogenesis) pada spesimen pasien osteosarkoma sebelum mendapatkan kemoterapi berhubungan dengan prognosa yang lebih baik dan respon yang lebih baik terhadap kemoterapi. ${ }^{33}$ Beberapa peneliti tidak menemukan hubungan antara ekspresi VEGF dengan parameter klinis dan survival. Ek mengevaluasi ekspresi VEGF dan CD31/34 sebagai penanda dari MVD ( Micro Vessel Density ) pada spesimen biopsi sebelum pemberian kemoterapi dan mendapatkan bahwa VEGF dan CD31/34 diekspresikan oleh hampir semua spesimen baik secara kuat maupun sedang. Namun tidak menemukan hubungan yang bermakna antara ekspresi VEGF, MVD, tampilan klinis patologis dan keluaran ( outcome ) dari osteosarkoma. ${ }^{34}$

Sznurkowska pada studinya membandingkan ekspresi VEGF dan MVD pada 16 pasien osteosarkoma yang mengalami metastase dan tidak dengan survival. Sznurkowska tidak menemukan perbedaan bermakna antara keduanya juga dengan survival pasien. ${ }^{35}$ Mizobuchi melakukan restrospektif studi terhadap 48 pasien osteosarkoma dengan derajat keganasan tinggi dan membandingkan ekspresi VEGF dan HIF-1a dengan survival dan parameter klinis pada pasien pasien ini. Mzobuchi tidak menemukan hubungan antara ekspresi VEGF dan survival ataupun parameter klinis yang lain. ${ }^{36}$

Mantadakis dalam studi retrospektif terhadap 29 pasien osteosarkoma tanpa metastasis dan bukan subtype chondroblastik menemukan bahwa tidak ada hubungan bermakna antara parameter angiogenesis ( MVD ) dengan survival dan kejadian metastasis pada pasien - pasien tersebut. ${ }^{37}$ Chen meneliti berbagai penanda biologis terhadap angiogenesis ( termasuk VEGF ) pada 35 pasien osteosarkoma dan tidak menemukan hubungan bermakna antara ekspresi penanda - penanda ini dengan survival maupun parameter keluaran yang lain ( kekambuhan maupun metastasis ). ${ }^{38}$ Jia pada percobaannya dengan model sel osteosarkoma (LM7) menemukan bahwa ekspresi VEGF tidak berhubungan dengan metastasis. ${ }^{39}$

Beberapa peneliti mempelajari ekspresi VEGF sebelum dan setelah mendapat neoadjuvant kemoterapi dan mencoba mencari hubungan antara perubahan ekspresi VEGF dengan parameter klinis. Huang membandingkan ekspresi VEGF dan $\alpha \mathrm{V}$ integrin pada spesimen biopsi dan setelah neoadjuvant kemoterapi ( adriamisin, cysplatin dan ifosfamid ) dan menemukan bahwa ekspresi VEGF dan $a \mathrm{~V}$ integrin yang kuat sebelum kemoterapi menjadi menurun drastis setelah neoadjuvant. Walau demikian ekspresi VEGF yang masih kuat setelah kemoterapi berhubungan dengan stadium Enneking yang lebih tinggi dan insiden kekambuhan dan metastasis yang lebih besar. ${ }^{40}$

Bajpai menganalisa ekspresi VEGF pada 31 preparat biopsi dan operasi (setelah neoadjuvant) pasien osteosarkoma dan menemukan bahwa ekspresi VEGF positif pada preparat biopsi berhubungan dengan grading histologi yang lebih tinggi. Penurunan ekspresi VEGF oleh sel tumor yang hidup pada preparat setelah neoadjuvant menunjukkan hubungan yang bermakna dengan nekrosis histologi yang lebih luas ( respon kemoterapi baik ). ${ }^{41}$

Rossi dalam studinya terhadap 16 spesimen pasien osteosarkoma saat biopsi dan setelah neoadjuvant kemoterapi yang termasuk Methotrexate (MTX) menemukan bahwa VEGF dan CD31 diekspresikan oleh spesimen biopsi dan ekspresi ini meningkat bermakna (untuk VEGF) setelah pemberian kemoterapi neoadjuvant. Peningkatan ekspresi VEGF setelah kemoterapi ini menandakan bahwa kemoterapi menyebabkan terjadinya peningkatan angiogenesis pada sel tumor. Ekspresi VEGF yang meningkat berhubungan bermakna dengan kekambuhan, metastase paru dan survival yang buruk. Rossi menyimpulkan bahwa pasien - pasien dengan ekspresi VEGF yang meningkat setelah kemoterapi adjuvant merupakan kandidat yang baik untuk menerima terapi anti 
angiogenesis. ${ }^{42}$

Pada penelitian ini ekspresi VEGF pada sel tumor yang masih hidup setelah pemberian neoadjuvant kemoterapi dihubungkan dengan parameter klinis dan survival. Tidak ditemukan hubungan yang bermakna antara ekspresi VEGF dengan parameter klinis (umur, jenis kelamin, lokasi tumor, ukuran tumor, kadar SAP, jenis tumor, dan stadium Enneking). Tidak didapatkannya hubungan antara stadium Enneking dan ekspresi VEGF lebih karena tidak seimbangnya sample $(94.7 \%$ merupakan stadium IIB).

Hasil penelitian ini juga sejalan dengan hasil yang didapatkan oleh Kreuter dkk. Hasil penelitian ini mendukung ide bahwa angiogenesis (meningkatnya kepadatan pembuluh darah dan atau dalam hal penelitian ini ekspresi VEGF) pada sarcoma yang berespon baik terhadap kemoterapi seperti osteosarkoma, akan meningkatkan hantaran regimen kemoterapi dan membuat regimen ini bekerja lebih baik. Hal ini secara berkaitan akan meningkatkan survival dari pasien tersebut apabila pasien diterapi dengan multidrug kemoterapi. Temuan Kreuter bahwa ekspresi VEGF positif berkaitan dengan respon kemoterapi yang baik (HUVOS 3,4) juga sejalan dengan penelitian ini. ${ }^{33}$

Ekspresi VEGF yang positif kuat dihubungkan dengan sifat tumor yang makin ganas. Ekspresi VEGF yang positif setelah neoadjuvant meningkatkan angiogenesis pada pasien dalam penelitian ini dan memfasilitasi pemberian adjuvant kemoterapi sehingga pasien dengan ekspresi VEGF positif lemah (bukan pasien dengan ekspresi negatif atau positif kuat) mempunyai survival terbaik. Dua pasien dengan VEGF positif kuat tidak mendapat adjuvant kemoterapi karena alasan sosial ekonomi. Tiga pasien dengan VEGF negatif juga tidak mendapat kemoterapi adjuvant karena alasan kondisi umum yang buruk dan satu pasien VEGF negatif datang pertama kali dengan metastasis di paru. Hal ini dapat pula menjelaskan mengapa pasien dengan ekspresi VEGF positif kuat dan negatif memiliki survival yang lebih buruk.

Keterbatasan dari penelitian ini adalah besarnya jumlah pasien yang hilang dari pengamatan (sebanyak 11 pasien atau lebih dari 50\%). Meskipun jumlah pasien yang hilang dari pengamatan tersebar merata antara pasien dengan ekspresi VEGF positif dan negatif namun hal ini tetap mempengaruhi kurva survival. Pada analisa multivariat didapatkan kesimpulan bahwa faktor yang mempengaruhi survival secara independent adalah ekspresi VEGF setelah neoadjuvant kemoterapi dan umur. Sekali lagi hasil ini dibatasi oleh sedikitnya jumlah sample yang dipakai dalam penelitian ini.

\section{KESIMPULAN}

VEGF merupakan salah satu penanda angiogenesis pada osteosarkoma. Hipoksia dalam tumor telah lama diketahui berhubungan dengan resistensi terhadap kemoterapi dan radioterapi demikian pula dengan sifat tumor yang lebih ganas. Tidak ditemukan hubungan yang bermakna antara ekspresi VEGF setelah kemoterapi neoadjuvant dengan karakteristik pasien. Terdapat kecenderungan bahwa ekspresi VEGF yang positif setelah kemoterapi neoadjuvant berhubungan dengan meningkatnya metastase, local recurrence, kadar SAP dan dengan respon histologi yang baik (HUVOS 3,4), namun hal ini tidak bermakna secara statistik.

\section{ETIKA PENELITIAN}

Penelitian ini telah mendapat persetujuan etik oleh Komisi Etik Fakultas Kedokteran Universitas Udayana, RSUP Sanglah, Bali sebelum berjalan

\section{KONFLIK KEPENTINGAN}

Tidak terdapat konflik kepentingan dalam penulisan laporan penelitian ini

\section{PENDANAAN}

Penulis bertanggung jawab secara mandiri terhadap pendanaan penelitian ini

\section{KONTRIBUSI PENULIS}

Penulis berkontribusi penuh terhadap penulisan laporan penelitian ini baik dari tahap kerangka konsep, pencarian data, analisis data, hingga laporan akhir penelitian.

\section{DAFTAR PUSTAKA}

1. Salter R. Diagnosis of Disorders and Injuries of Musculoskeletal System. $3^{\text {rd }}$ ed. Philadelphia: LippincottWilliams-Wilkins 1999;14:400-403.

2. Unni KK. Dahlin's Bone Tumors. General Data on 11,087 Cases. $5^{\text {th }}$ ed. Philadelphia: Lippincott-Raven Publishers, 1996:143-96.

3. Perkumpulan Ahli Bedah Orthopaedi. Buku Besar Tumor Bagian Orthopaedi FKUI. Edisi 2. Jakarta. 2008

4. Raymond AK, Ayala AG, Knuutila S et al. Conventional Osteosarcoma. World Health Organization Classification of Tumours of Soft Tissue and Bone. $1^{\text {st }}$ ed. Lyon: IARC Press, 2002:264-85.

5. Unni KK, Inwards CY, Bridge JA. Tumors of the Bones and Joints. 4th ed. Silver Spring: ARP Press, 2005:135-92.

6. Meyers PA, Schwartz CL, Krailo M, et al. Osteosarcoma: A Randomized, Prospective Trial of the addition of Ifosfamide and/or Muranyl Tripeptide to Cisplatin, Doxorubicin, and High-Dose Methotrexate. J Clin Oncol. 2005;23(9):200411.

7. Leung KS, Fung KP, Sher AHL, et al. Plasma Bone-Specific Alkaline Phosphatase as an Indicator of Osteoblastic 
Activity. J Bone Joint Surg. 1993;75(2):288-92.

8. Bielack SS, Kempf-Bielack B, Delling G, et al. Prognostic Factors in High-Grade Osteosarcoma of the Extremities or Trunk: An Analysis of 1,702 Patients Treated on Neoadjuvant Cooperative Osteosarcoma Study Group Protocols. J Clin Oncol. 2002;20(3):776-90.

9. Ward WG, Mikaelian K, Mirra JM et al. Pulmonary metastases of Stage IIB Extremity osteosarcoma and subsequent Pulmoonary metastases. J Clin Oncol. 1994;12(9):1849-58.

10. Bacci G, Longhi A, Versari M, et al. Prognostic Factors for Osteosarcoma of the Extremity Treated by Neoadjuvant Chemotherapy: 15 years experience in 789 patients treated at a single institution. J Bone Joint Surg. 2006;106(5):115461.

11. Kager L, Zoubek A, Pootschger U, et al. Primary Metastatic Osteosarcoma: Presentation and Outcome of Patients Treated on Neoadjuvant Cooperative Osteosarcoma Study Group Protocols. J Clin Oncol. 2003;21(10):2011-18.

12. Wunder JS, Paulin G, Huvos AG, et al. The histological response to chemotherapy as a predictor of oncologic outcome of operative treatment of Ewing Sarcoma. J Bone Joint Surg Arm. 1998;80(7):1020-1033

13. Unni KK. Osteosarcoma. In: Dahkin's Bone Tumors: General Aspects and Data on 11087 Cases, Ed 5th. Philadelphia: Lippincott-Raven Publishers, 1996:143-184.

14. Enneking WF, Spanier SS, Goodman MA. A system for the surgical staging of musculoskeletal sarcoma. 1980. Clin Orthop Relat Res. 2003;(415):4-18

15. The JOA Musculo-Skeletal Tumor Committee. General Rules for Clinical and Pathological Studies on Malignant Bone Tumors, Ed. 2. Tokyo: Kanabara, 1990.

16. Rosen G, Huvos AG, Marcove R, Nirenberg A. Telangiectatic osteogenic sarcoma. Improved survival with combination chemotherapy. Clin Orthop Relat Res. 1986;(207):164-73.

17. Winkler K, Beron G, Delling G, et al. Neoadjuvant chemotherapy of osteosarcoma: Results of a randomized cooperative trial (COSS-82) with salvage chemotherapy based on histological tumor response. J Clin Oncol. 1988;6(2):329-37.

18. Bacci G1, Picci P, Ruggieri P, et al. Primary chemotherapy and delayed surgery (neoadjuvant chemotherapy) for osteosarcoma of the extremities. The Istituto Rizzoli Experience in 127 patients treated preoperatively with intravenous methotrexate (high versus moderate doses) and intraarterial cisplatin. Cancer. 1990;65(11):2539-53.

19. Glasser DB, Lane JM, Huvos AG, et al. Survival, prognosis and therapeutic response in osteogenic sarcoma: the Memorial Hospital Experience. Cancer. 1992;69(3):698708.

20. Souhami RL, Craft AW, Van der Eijken JW, et al. Randomized trial of two regimens of chemotherapy in operable osteosarcoma: a study of the European osteosarcoma intergroup. Lancet. 1997;350(9082):911-7.

21. Asai $\mathrm{T}$, Ueda $\mathrm{T}$, Itoh $\mathrm{K}$, et al. Establishment and characterization of a murine osteosarcoma cell line (LM8) with high metastatic potential to the lung. Int J Cancer. 1998;76(3):418-22.

22. Mori S, Ueda T, Kuratsu S, et al. Suppression of pulmonary metastasis by angiogenesis inhibitor TNP- 470 in murine osteosarcoma. Int J Cancer. 1995;61(1):148-52.

23. Bettencourt MC, Bauer JJ, Sesterhenn IA, et al. CD34 immunohistochemical assessment of angiogenesis as a prognostic marker for prostate cancer recurrence after radical prostatectomy. J Urol. 1998;160(2):459-65.

24. Maeda K, Chung YS, Ogawa Y, et al. Prognostic value of vascular endothelial growth factor expression in gastric carcinoma. Cancer. 1996;77(5):858-63.

25. Ishigami SI, Arii S, Furutani M, et al. Predictive value of vascular endothelial growth factor (VEGF) in metastasis and prognosis of human colorectal cancer. $\mathrm{Br}$ J Cancer. 1998;78(10):1379-84.

26. Inoue K, Ozeki Y, Suganuma T, et al. Vascular endothelial growth factor expression in primary esophageal squamous cell carcinoma. Cancer. 1997;79(2):206-13.

27. Shindoh M, Higashino F, Kaya M, et al. Correlated expression of matrix metalloproteinases and ets family transcription factor E1A-F in invasive oral squamous-cell -carcinomaderived cell lines. Am J Pathol. 1996;148(3):693-700.

28. Lee $\mathrm{YH}$, Tokunaga $\mathrm{T}$, Oshika $\mathrm{Y}$, et all, Cell-retained isoforms of vascular endothelial growth factor (VEGF) are correlated with poor prognosis in osteosarcoma. Eur J Cancer. 1999;35(7):1089-93.

29. Kaya M, Wada T, Akatsuka T, et al. Vascular endothelial growth factor expression in untreated osteosarcoma is predictive of pulmonary metastasis and poor prognosis. Clin Cancer Res. 2000;6(2):572-7.

30. Charity RM, Foukas AF, Deshmukh NS, et al. Vascular endothelial growth factor expression in osteosarcoma. Clin Orthop Relat Res. 2006;448:193-8.

31. Zhou $Q^{1}$, Zhu $Y$, Deng Z, et al. VEGF and EMMPRIN expression correlates with survival of patients with osteosarcoma. Surg Oncol. 2011;20(1):13-9

32. Oda $Y^{1}$, Yamamoto H, Tamiya S, et al. CXCR4 dan VEGF expression in the primary site and the metastatic site of human osteosarcoma: analysis within a group of patients, all of whom developed lung metastasis. Mod Pathol. 2006;19(5):738-45.

33. Kreuter M, Bieker R, Bielack SS, et al. Prognostic relevance of increased angiogenesis in osteosarcoma. Clin Cancer Res. 2004;10(24):8531-7.

34. Ek ET, Ojaimi J, Kitagawa Y, et al. Outcome of patients with osteosarcoma over 40 years of age: is angiogenesis a marker of survival? Int Semin Surg Oncol. 2006;3:7.

35. Sznurkowska K, Lenckowski R, Popadiuk S, et all. Assessment of angiogenesis in children's osteosarcoma. Med Wieku Rozwoj. 2006;10(3 Pt 1):737-44.

36. Mizobuchi H, García-Castellano JM, Philip S, et al. Hypoxia Markers in Human Osteosarcoma An Exploratory Study. Clin Orthop Relat Res. 2008;466(9):2052-9.

37. Mantadakis E, Kim G, Reisch J, et al. Lack of prognostic significance of Intratumoral angiogenesis in nonmetastatic osteosarcoma. J Pediatr Hematol Oncol. 2001;23(5):286-9.

38. Chen W, He M, Aisner S, et all. Expression of cell cycle, angiogenesis and metastases associated factors in osteosarcoma - immunohistochemical analysis of tissue array in 35 patients. Journal of Clinical Oncology. 2007;25(18S):10036

39. Jia SF, Guan H, Duan X, et al. VEGF did not enhance lung metastasis potential of human osteosarcoma cells. Proc Amer Assoc cancer Res. 2006;47:4330

40. Huang Y, Lin Z, Zhuang J, Chen Y, Lin J, Prognostic significance of alpha $\mathrm{V}$ integrin and VEGF in osteosarcoma after chemotherapy, Onkologie; 2008;31(10):535-40

41. Bajpai J, Sharman M, Sreenivas V, et al. VEGF expression as a prognostic marker in osteosarcoma. Pediatr Blood Cancer. 2009;53(6):1035-9.

42. Rossi B, Schinzari G, Maccauro G, et al. Neoadjuvant multidrug chemotherapy including High-Dose Methotrexate modifies VEGF expression in Osteosarcoma: an immunohistochemical analysis. BMC Musculoskelet Disord. 2010;11:34.

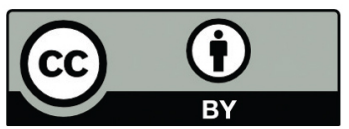

This work is licensed under a Creative Commons Attribution 